LWSA

PAPER - OPEN ACCESS

\title{
Relasi Gramatikal Subjek Bahasa Pakpak Dairi: Kajian Tipologi
}

\author{
Author \\ : Ida Basaria \\ DOI \\ : 10.32734/lwsa.v1i1.140 \\ Electronic ISSN \\ : 2654-7058 \\ Print ISSN \\ : 2654-7066 \\ Volume 1 Issue 1 - 2018 TALENTA Conference Series: Local Wisdom, Social and Arts
}

\section{(a) $(1) \Theta$}

This work is licensed under a Creative Commons Attribution-NoDerivatives 4.0 International License.

Published under licence by TALENTA Publisher, Universitas Sumatera Utara
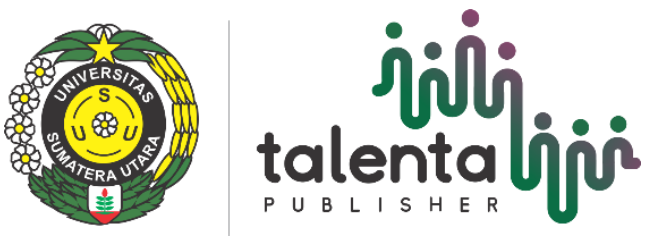


\title{
Relasi Gramatikal Subjek Bahasa Pakpak Dairi: Kajian Tipologi
}

\author{
Ida Basaria ${ }^{a}$ \\ ${ }^{a}$ Fakultas Ilmu Budaya, Universitas Sumatera Utara, Medan-20155, Indonesia \\ ida1@usu.ac.id
}

\begin{abstract}
Abstrak
Secara etimologis, kata tipologis berarti pengelompokan ranah (classification of domain). Pengertian tipologi bersinonim dengan istilah taksonomi. Istilah teknis tipologi yang masuk ke dalam linguistik mempunyai pengertian pengelompokan bahasa-bahasa berdasarkan ciri khas strukturnya. Kajian ini berusaha mencermati fitur-fitur dan ciri-ciri khas gramatikal bahasa-bahasa di dunia, dan membuat pengelompokan yang bersesuaian dengan parameter tertentu. Kajian tipologi bahasa umumnya dimaksudkan untuk mengklasifikasikan bahasa berdasarkan perilaku struktural yang ditampilkan oleh suatu bahasa. Tujuan kajian tipologi bahasa terutama diarahkan untuk menjawab pertanyaan: seperti apa bahasa $x$ itu? Kajian tipologis terhadap BPD, sebagai salah satu bahasa daerah di Sumatera Utara (termasuk kelompok bahasa Austronesia Barat), cukup penting dan bernilai ilmiah untuk dilakukan. Hal ini disebabkan oleh kenyataan bahwa sampai saat ini masih terdapat banyak pendapat tentang pengelompokan secara tipologis bahasa-bahasa daerah di Indonesia.Relasi gramatikal memegang peranan penting dalam sintaksis bahasa alamiah, karena berhubungan dengan sejumlah konsep dan istilah sintaksis (gramatikal) seperti S(ubjek), O dan OBLik. Dengan menggunakan metode deskriptif melalui uji gramatikal dan dengan pendekatan teori tipologi linguistik dapat disimpulkan bahwa relasi S pada klausa dasar BPD selalu berperan sebagai Agen; Subjek pada klausa berprefiks nasal pada posisi FN2 pos-Verbal yang merupakan argumen Agen; sementara itu FN1pos Verba adalah ditempati oleh argumen Pasien. Pada BPD, Subjek dan Objek pada klausa verba zero senantiasa dapat direlatifkan; sementara pada klausa verba berafiks nasal hanya relasi $\mathrm{S}$ yang dapat direlatifkan. Relasi O merupakan FN yang langsung mengikuti verba dan tak dapat disisipi oleh adverbia apapun. Relasi O dapat dinaikkan posisinya menjadi S pada pemasifan BPD; sementara itu S kalimat asal menjadi relasi OBL.
\end{abstract}

Kata kunci : Relasi gramatikal; tipologi linguitik; subjek, objek; oblik

\section{Pendahuluan}

Penelitian Bahasa Pakpak Dairi (selanjutnya disingkat BPD) belum menggembirakan sama halnya dengan pemertahanan BPD oleh penuturnya, yang juga sangat mengkhawatirkan. Hal ini disebabkan BPD sangat jarang digunakan, apalagi bila bertemu dengan suku bangsa Toba. Di samping itu, ada kecenderungan sikap generasi muda masyarakat penuturnya yang merasa rendah diri atau malu dianggap orang tak terpelajar jika menggunakan BPD. Mereka lebih suka menggunakan bahasa Indonesia dalam pergaulan sehari-hari, baik dalam lingkungannya sendiri, maupun di luar lingkungannya. (Solin,2000:112). Bahasa yang jarang digunakan lambat laun akan dapat menjadi bahasa yang bergeser (terkontaminasi) dan mati, demikian juga BPD ini. Kalau semakin jarang digunakan karena dominannya bahasa Toba dan juga bahasa Indonesia, tidak mustahil BPD akan hilang dari "peredaran". Di Indonesia menurut Gunarwan (2002), ada 169 bahasa daerah yang terancam punah dan mengacu pada ciri yang disebut Grimes (2002), BPD dapat dimasukkan ke dalam kelompok bahasa yang terancam punah. Meskipun dengan angka keterancaman sebanyak itu, kita belum mempunyai program dan tradisi preservasi yang kuat untuk 
menyelamatkannya dari kepunahan, kecuali baru pada tingkat dokumentasi melalui penelitian individu, perguruan tinggi, atau oleh pusat bahasa. Dan penelitian ini salah satu usaha pengenalan BPD dan sekaligus usaha terhadap kelestariannya.

Relasi gramatikal memegang peranan penting dalam sintaksis bahasa alamiah, karena berhubungan dengan sejumlah konsep dan istilah sintaksis (gramatikal) seperti Subjek, Objek Langsung (OL) dan Objek Tak Langsung (OTL). Dalam Tatabahasa Relasionalistilah relasi gramatikali itu adalah S, OL, OTL, dan relasi oblik (OBL). Artawa (2000: 490) menyebutkan relasi gramatikal tersebut menjadi acuan untuk menjelaskan berbagai aspek srtuktur klausa serta prinsip-prinsip semesta yang menguasai struktur dan organisasi sintaksis bahasa alami.

Pengertian dan konsep dasar relasi gramatikal berdasar pada pendapat yang dikemukakan oleh Comrie (1989: 65), menyebutkan bahwa relasi gramatikal (baik menurut pendapat tradisional maupun dalam tulisan mutakhir) adalah bagian-bagian atau unsur dari kalimat/klausa yang dikategorikan sebagai subjek (S), objek langsung (OL), dan objek tak langsung (OTL). Tiga relasi gramatikal tersebut adalah relasi yang bersifat sintaksis. Di samping relasi gramatikal yang bersifat sintaksis, ada relasi yang bersifat semantik, yaitu: lokatif, benefaktif, dan instrumental yang secara kolektif disebut relasi oblik. (Blake,1991 dalam Artawa, 2000:490)

Blake mengemukakan bahwa relasi sintaksis dianggap membentuk hierarki dengan penomoran 1, 2, 3 yang umumnya digunakan untuk menandai relasi yang bersangkutan:

$\begin{array}{llll}\mathrm{S} & \text { OL } & \text { OTL } & \text { OBL } \\ 1 & 2 & 3 & \end{array}$

Pada strata awal (initial), agen diperlakukan sebagai relasi 1; pasien sebagai relasi 2; dan resipien sebagai relasi 3. Relasi- relasi gramatikal tersebut menjadi acuan untuk memerikan berbagai aspek srtuktur klausa serta prinsipprinsip semesta yang menguasai struktur sintaksis bahasa alami. Relasi-relasi gramatikal diperlukan untuk mencapai tiga sasaran teori bahasa, yaitu (1) merumuskan kesemestaan bahasa; (2) menetapkan karakteristik setiap konstruksi gramatikal yang ada pada bahasa- bahasa alami; (3) membangun suatu tatabahasa yang memadai untuk setiap bahasa. Untuk maksud tersebut, suatu teori tatabahasa harus mengkaji data umum bahasa, yang berlaku untuk semua bahasa, dan data khusus bahasa yang berlaku hanya untuk bahasa-bahasa tertentu. Relasi-relasi gramatikal dalam hal ini memberikan suatu konsep yang tepat, baik tentang cara kerja bahasa pada umumnya (sasaran (1) dan (2), maupun tentang cara memerikan bahasa-bahasa tertentu (sasaran (3) (Blake,1991; Artawa, 2000:490; lihat Jufrizal 2004:55).

Struktur argumen yang membangun klausa yang terdiri atas agen dan pasien, yang dimarkahi oleh fitur- fitur gramatikal dalam sebuah bahasa disebut dengan peran gramatikal. Sementara itu, konsep relasi gramatikal meliputi subjek, objek dan sebagainya yang merupakan fungsi-fungsi sintaksis dalam sebuah bahasa. Kajian dan bahasan tentang seluk-beluk relasi gramatikal BPD akan sangat bermanfaat bagi pengetahuan teori dan konsep kesemestaan bahasa secara umum karena sangat jelas berhubungan dengan sejumlah konsep dan istilah sintaksis lainnya.

Mallison dan Blake (1981: 4-5) menyebutkan bahwa penelitian generalisasi lintas bahasa atau kesemestaan bahasa (language universals) dikenal luas sebagai pokok pikiran utama di belakang penelitian tipologi skala besar. Seperti halnya dengan tipologi bahasa, semestaan bahasa meliputi juga ciri fonologis, morfologis, dan sintaksis. Ciri-ciri kebahasaan yang tidak meliputi semua atau hampir semua bahasa di dunia tidak akan diperhitungkan sebagai kesemestaan bahasa, tetapi akan berguna bagi tipologi bahasa. Sebab itu, antara semestaan bahasa dan tipologi bahasa terdapat hubungan timbal balik, tetapi di pihak lain terdapat juga perbedaan yang jelas. Penelitian kesemestaan bahasa menghendaki kajian tipologis yang dilakukan secara silang seluas mungkin. Pada pertengahan abad ke-20, kajian tipologi dan kesemestaan bahasa dilakukan berdampingan.

Comrie (1989:30-32) juga menyebutkan bahwa terdapat saling keterkaitan antara kesemestaan bahasa dan tipologi karena keduanya berjalan bergandengan. Kajian kesemestaan bahasa berusaha menemukan (1) perilaku dan sifatsifat yang umum bagi semua bahasa manusia; (2) mencari/ menemukan kemiripan yang ada dalam lintas bahasa; dan (3) berusaha menetapkan batas-batas variasi dalam bahasa manusia. Sedangkan penelitian tipologi berusaha (1) mengelompokkan bahasa-bahasa, yaitu menetapkan bahasa- bahasa ke kelompok/ tipe yang berbeda; (2) mengkaji perbedaan antara bahasa-bahasa; dan (3) mempelajari variasi-variasi bahasa manusia. Untuk menetapkan tipologi bahasa, perlu ditetapkan parameter tertentu untuk mengelompokkan bahasa di dunia. Menetapkan tipologi bahasa 
diperlukan asumsi tentang kesemestaan bahasa. Istilah kesemestaan bahasa bukan berarti seluruh bahasa mempunyai fitur atau kasus yang sama, melainkan hanya bersifat hampir keseluruhan (kecenderungan umum). Jadi istilah lain dari kesemestaan bahasa dipakai/disebut juga generalisasi lintas bahasa.

\section{Tinjauan pustaka}

\subsection{Tiponologi linguistik}

Secara etimologis, kata tipologis berarti pengelompokan ranah (classification of domain). Pengertian tipologi bersinonim dengan istilah taksonomi. Istilah teknis tipologi yang masuk ke dalam linguistic mempunyai pengertian pengelompokan bahasa-bahasa berdasarkan ciri khas strukturnya. Diantara bentuk kajian tipologi linguistik pada periode awal yang terkenal adalah word order typology atau tipologi tataurut dasar yang dilakukan oleh Greenberg (Comrie1998:35). Kajian ini berusaha mencermati fitur-fitur dan ciri-ciri khas gramatikal bahasa-bahasa di dunia, dan membuat pengelompokan yang bersesuaian dengan parameter tertentu, yang dikenal dalam dunia linguistik sebagai kajian tipologi linguistik (linguistic typology). Hasil kajian seperti itu melahirkan tipologi bahasa; pengelompokan bahasa-bahasa dengan sebutan tertentu [7].

Ada empat jenis tahap analisis tipologis, yaitu (i) penentuan fenomena yang akan dipelajari. Dalam hal ini diperlukan pembatasan dan kejelasan gejala variasi struktural bahasa yang akan dikaji. Langkah ini amat penting artinya karena begitu rumitnya pertautan antara unsur-unsur bahasa, baik dalam bahasa itu sendiri maupun antara bahasa; (ii) pengelompokan tipologis fenomena yang sedang diteliti. Tahap ini memerlukan pencermatan dan penelaahan data secara sungguh-sunguh, disertai pemahaman teori yang memadai; (iii) merumuskan simpulan umum (generalisasi) atas pengelompokan tersebut. Tahap ini memerlukan kepekaan dan kejelian linguistik untuk dapat merumuskan simpulan-simpulan teoritis yang bersesuaian dengan keadaan dan watak data; dan (iv) menjelaskan tiap generalisasi atau rumusan teoritis yang dibuat. Tahap ini menjadi ukuran dan penentu bagi kebermaknaan temuan yang diperoleh [7].

Tipologi linguistik bukanlah teori tatabahasa, sebagaimana halnya teori TG atau teori tata bahasa lain yang dirancang untuk memodelkan bagaimana bahasa bekerja. Tipologi linguistik adalah bentuk kajian ketatabahasaan yang bertujuan untuk mengidentifikasi pola-pola linguistik secara lintas bahasa dan hubungan antara pola-pola tersebut. Oleh karena itu, teori tipologi linguistik akan bersesuaian saja dengan teori tatabahasa yang ada. Walaupun penelitian ini, seperti yang telah diuraikan pada bagian terdahulu, hanya dititikberatkan pada kajian sintaksisnya (gramatikalnya), namun untuk memperkuat kajian ini maka kajian tipologi morfologis, semantis, dan pragmatis akan disinggung pula.

\subsection{Konsep relasi gramatika}

Pengertian dan konsep dasar fungsi dan relasi gramatikal berdasar pada pendapat yang dikemukakan oleh Comrie (1998 : 65), yang menyebutkan bahwa fungsi gramatikal (baik menurut pendapat tradisional maupun dalam tulisan mutakhir ) adalah bagian-bagian atau unsur dari kalimat / klausa yang dikategorikan sebagai subjek (S), objek langsung (OL), dan objek tak langsung (OTL). Tiga fungsi dan relasi gramatikal tersebut adalah relasi yang bersifat sintaksis. Di samping fungsi gramatikal yang bersifat sintaksis, ada fungsi relasi yang bersifat semantik, yaitu : lokatif, benefaktif, dan instrumental yang secara kolektif disebut relasi oblik (Artawa, 2000:490).

Relasi gramatikal menjadi acuan untuk memerikan berbagai aspek srtuktur klausa serta prinsip-prinsip semesta yang menguasai struktur dan organisasi sintaksis bahasa alami. Fungsi dan relasi gramatikal diperlukan untuk mencapai tiga sasaran teori bahasa, yaitu (1) merumuskan kesemestaan bahasa; (2) menetapkan karakteristik setiap konstruksi gramatikal yang ada pada bahasa-bahasa alami; (3) membangun suatu tatabahasa yang memadai untuk setiap bahasa. Untuk maksud tersebut, suatu teori tatabahasa harus mengkaji data umum bahasa, yang berlaku untuk semua bahasa, dan data khusus bahasa yang berlaku hanya untuk bahasa-bahasa tertentu. Relasi-relasi gramatikal dalam hal ini memberikan suatu konsep yang tepat, baik tentang cara kerja bahasa pada umumnya (sasaran (1) dan (2), maupun tentang cara memerikan bahasa-bahasa tertentu (sasaran (3).

Relasi gramatikal yang bersifat sintaksis (S, OL, OTL) dan relasi yang bersifat semantis (OBL) akan dianalisis dengan pendekatan teori tipologi linguistik dengan tujuan utama merinci penelaahan tentang struktur dasar BPD. 
Topik-topik telaahan yang bersangkutpaut dengan relasi gramatikal yang menjadi kajian penelitian ini adalah kesubjekan dan subjek, objek dan relasi oblik. Comrie (1998: 104) menyebutkan prototipe (hakekat asal) subjek itu adalah memperlihatkan adanya saling terkait antara agen dan topik. Artinya maksud yang paling jelas dari subjek itu, secara lintas bahasa adalah bahwa subjek itu agen dan juga topik. Namun dalam penelitian ini, pengujian sifat perilaku subjek BPD akan didasarkan pada sifat perilaku gramatikal.

Sifat perilaku subjek secara lintas bahasa bukanlah nilai mutlak. Mungkin saja ada sebagian sifat perilaku tersebut yang tidak benar-benar cocok untuk perilaku bahasa tertentu. Pengujian sifat perilaku subjek yang didasari oleh sifat perilaku gramatikal telah dilakukan oleh Artawa (2000:11-17) terhadap bahasa Bali. Menurutnya karena subjek adalah relasi gramatikal, maka penentuan/penetapan subjek dalam suatu bahasa hendaknya didasarkan pada sifat perilaku gramatikal. Berkaitan dengan ini, hakekat kesubjekan dilihat berdasarkan pengertian: (1) pronomina tidak-terang (PRO), (2) penaikan (raising), (3) perefleksivan, (4) pengambangan penjangka (quantifier float), (5) perelatifan (relativisation).

\section{Tinjauan pustaka}

Penelitian ini menggunakan metode deskriptif dengan pendekatan kualitatif yang berorientasi kepada studi fenomenologis yang bukan matematis. Menurut Bogdan dan Taylor (1992:5) metode penelitian kualitatif sebagai prosedur penelitian yang menghasilkan data deskriptif berupa kata-kata (bisa lisan untuk penelitian sosial, budaya, filsafat). Deskripitif bukanlah berarti hanya sekedar memberi gambaran apa adanya tentang relasi dan peran gramatikal dalam BPD, melainkan sampai pada penemuan dan perumusan pola-pola yang berlaku pada relasi gramatikal Subjek, Objek dan Oblik BPD. Metode yang digunakan dalam menganalisis data penelitian ini adalah metode agih (Soedaryanto, 1993: 15 dan Mahsun, 2011: 102-142). Dengan menggunakan teknik ganti dan teknik ubah-ujud dalam metode agih tersebut terhadap berbagai jenis klausa dan kalimat BPD yang menjadi data penelitian akan diperoleh simpulan yang berupa ‘sistem’ yang mengatur relasi gramatikal Subjek, BPD.

\section{Hasil dan pembahasan}

\subsection{Relasi gramatikal BPD}

Fungsi dan relasi gramatikal adalah dua istilah yang sama- sama mengacu pada bagian-bagian unsur dari suatu klausa yang dikategorikan sebagai subjek (S), objek langsung (OL), dan objek tak langsung (OTL). Tiga jenis fungsidan relasi gramatikal ini adalah yang bersifat sintaksis. Di samping itu, ada fungsi gramatikal yang bersifat semantis, yaitu lokatif, benefaktif, dan instrumental (alat) yang secara kolektif disebut relasi oblik. Jadi fungsi gramatikal meliputi subjek, objek langsung, objek tak langsung, dan relasi oblik (Comrie, 1083:59; Blake, 1990:1; lihat juga Artawa (1998, 2000).

Fungsi gramatikal tersebut perlu ditelaah satu persatu dengan berlandaskan teori tipologi linguistik. Analisis tentang bagaimana relasi gramatikal BPD ini meliputi analisis tentang sifat perilaku subjek BPD.

\subsection{Relasi gramatikal subjek $B P D$}

Subjek (basic subject) secara lintas bahasa mempunyai ciri dan sifat perilaku khas yang dapat dikelompokkan menjadi empat: a) sifat perilaku otonomi; b) sifat-perilaku kasus; c) peran semantis; d) dominasi langsung (immediate dominance). Sifat perilaku otonomi subjek meliputi: (a) keberadaannya bebas (independent existence); (b) ketidaktergusuran /sangat diperlukan (indispensability); (c) rujukan sendiri (autonomous reference). Sifatperilaku pemarkah kasus meliputi: (1) subjek kalimat intransitif umumnya tidak dimarkahi jika setiap frasa nomina (FN) dalam bahasa tersebut tidak bermarkah; (2) FN yang mengubah penanda kasusnya pada pengkausatifan termasuk subjek; (3) FN yang mengubah penanda kasus nominalisasi tindakan termasuk subjek. Peran semantis (agen, pemengalam, dsb) dari subjek dapat diramalkan dari bentuk verba utama. Berdasarkan peran semantis ini, kesubjekan dapat diungkapkan: (1) subjek biasanya mengungkapkan agen (dari tindakan), jika hanya satu; (2) subjek biasanya mengungkapkan frasa tujuan (addressee phrase) bentuk imperatif; (3) subjek biasanya memperlihatkan posisi, pemarkah kasus, dan persesuaian verba yang sama dengan FN penyebab dalam jenis kalimat 
kausatif yang paling dasar. Sementara itu, dominasi langsung berarti bahwa subjek itu secara langsung didominasi langsung oleh simpul dasar S (sentence); lihat Li (ed.), (1976) dalam Jufrizal (2007 : 33).

Sifat perilaku subjek secara lintas bahasa seperti di atas bukanlah nilai mutlak. Karena mungkin saja ada sebagian sifat perilaku tersebut yang tidak benar-benar cocok untuk perilaku bahasa tertentu. Pengujian sifat perilaku subjek yang didasari oleh sifat perilaku gramatikal telah dilakukan oleh Artawa (1998: 11 -17) terhadap bahasa Bali. Menurutnya karena subjek adalah relasi gramatikal, maka penentuan/penetapan subjek dalam suatu bahasa hendaknya didasarkan pada sifat perilaku gramatikal. Berkaitan dengan ini, hakekat kesubjekan dilihat berdasarkan pengertian :(1) penaikan (raising), (2) perefleksivan, (3) pengambangan penjangka (quantifier float), (4) perelatifan (relativisation).

Temuan data kesubjekan BPD dalam penelitian ini dianalisis berdasarkan pengujian yang bersifat gramatikal seperti yang dikemukakan oleh Artawa (1998).

\subsubsection{Uji subjek dengan kaidah penaikan}

Kaidah penaikan adalah sebuah kategori gramatikal (sintaksis) yang sebelumnya bukan subjek dapat dinaikkan ke posisi subjek. (Postal, 1974; Artawa, 1998: 12)

Contoh:

(5a) mulakinang melgang

pulang 3TG masak 'pulang ibu untuk masak'

(5b) mulakmelgang inang

pulang masak 3TG 'ibu pulang (untuk) masak'

(6a) Tereluhinang tikan mulak

Menangis 2TG ketika pulang 'menangis Ibu ketika pulang'

(6b) Inangtereluhtikan mulak

2TG menangis ketika pulang 'Ibu menangis ketika pulang'

Kalimat (5a) adalah kalimat yang terdiri atas sebuah adjektiva (mulak) dengan satu klausa (inangmelgang) sebagai argumennya. Isi atau maksud pernyataan klausa (5a) tersebut dapat diungkapkan sebagai satu klausa tunggal seperti yang diwujudkan dengan klausa (5b). Inangpada (5a) dinaikkan dari klausa pemerlengkap menjadi subjek dari predikat mulak. Penjelasan analisis yang sama berlaku pada contoh (6a) dan (6b).

Dalam klausa transitif dengan verba tanpa afiks uji penaikan subjek dapat dibuktikan sebagai berikut.

Contoh:

(7a) maolember iembah dedahen

susahember ART adik bawa 'susahember itu adik bawa'

(7b) ember i maoldedahenembah

ember ART susah adik bawa

'ember itu susah adik bawa'

$(7 c) *$ dedahenmaolember i embah

Adik susahember ART bawa

'Adiksusah ember itu bawa'

Kalimat verbal transitif dengan konstruksi tanpa afiks, mempunyai dua FN yang keduanya terletak sebelum verba (FN pra-verbal). Pada contoh (7a) dua FNember i dan dedahen merupakan FN pra-verba. Apabila FN urutan pertama (ember i) dinaikkan untuk menempati posisi subjek (7b), kalimat itu berterima. Namun apabila FN urutan kedua (dedahen) dinaikkan untuk mmenempati posisi subjek $(7 \mathrm{c})$, kalimat itu tidak berterima (ditandai *). Dengan 
demikian, FN urutan pertama (yang berada tidak langsung sebelum verba) merupakan subjek gramatikal dalam kalimat transitif BPD apabila verbanya tanpa afiks.

\subsubsection{Uji subjek dengan perefleksifan}

Pada umumnya bahasa di dunia menempatkan agen (pelaku) sebagai pengontrol FN refleksif. Dalam bahasa Inggris misalnya, agen merupakan bentuk pilihan tak bermarkah untuk subjek. Artawa (1998:16; Jufrizal, 2007: 133) menyebutkan bahwa agen yang menjadi pengontrol perefleksivan merupakan kebenaran umum. Argumen agen pada satu klausa selalu merupakan anteseden yang mungkin dari bentuk reflektif dalam klausa tersebut. Dalam Bahasa Bali, Bahasa Tagalog dan Bahasa Minangkabau agen juga selalu pengontrol bentuk refleksif, apapun fungsi gramatikalnya.

Dalam penelitian ini, bentuk refleksif BPD diungkapkan dengan bentuk diri na sandiri atau diri sambaing.

Contoh:

(8a)Bapa me -nangiangken diri na sandiri

3TG AKT- doa diri sendiri 'bapa mendoakan diri sendir'

(8b)Turang men -cendai diri na sandiri

3TG AKT luka diri sendiri 'abang melukai diri sendiri'

Dalam contoh di atas, agenBapa dan Turang merupakan subjek gramatikal klausa yang bersangkutan. Bentuk refleksif yang diungkapkan dengan diri na sandiri dikontrol oleh agen. Jadi pada BPD, agen mengontrol perefleksifan pada klausa transitif dengan verba berprefiks nasal seperti contoh (8a) dan (8b)

\subsubsection{Uji subjek dengan pengambangan penjangka}

Pengambangan penjangka adalah kata bantu bilangan (quantifier) tak takrif yang merupakan penentu penunjuk jumlah (Moussay,1998: 162, lihat juga Jufrizal 2007: 37). Penjangka tak takrif dalam BPD dapat digolongkan atas (i) jumlahtidak pasti sedikit 'citok'; banyak 'mbueh'; bermacam-macam, berjenis-jenis 'meragam'; (ii) jumlah distributif: tiap, setiap, tiap-tiap 'ganup' (iii) jumlah kolektif: semua, segala, segenap 'kerina'; karinana 'sekaliannya'. Penjangka yang menunjukkan jumlah tak pasti dan distributif dalam kalimat BPD digunakan pada posisi sebelum FN. Sedangkan penjangka yang menunjukkan jumlah kolektif, bisa digunakan pada posisi sebelum atau sesudah FN Penjangka yang bisa digunakan pada lebih satu posisi (mengambang) dalam BPD adalah kerina 'semua', kerinana 'semuanya' Untuk menguji kesubjekan BPD sehubungan dengan pengambangan penjangka (quantifier float), perhatikan contoh klausa intransitif berikut ini

(9a) kerina keluarga- na laus

semua keluarga-POS3TG pergi

'semua keluarganya pergi'

(9b) lauskeluarga- na kerina

Pergi keluarga POS3TG semua

'semua keluarganya pergi'

(9c)keluargana laus kerina

Keluarganya pergi semua

'semua keluarganya pergi'

(9d) Kerina laus keluarga- na

semua pergikeluarga POS3TG

'keluarganya semua pergi'

(10a)kerina turangna karejo

Kerja semua abang -POS3TG

'semua abangnya kerja'

(10b)Kerejoturang-na kerina

Kerja abang-POS3TG semua 
'semua abangnya kerja'

(10c)Kerina kerejo turang-na

semua kerjaabang-POS3TG

'semua abangnya kerja'

(10d) turang-na kerina kerejo

Abangnya semua kerja

'semua abangnya kerja'

Dalam klausa intransitif BPD seperti terlihat pada $(9,10, a, b, c, d)$ posisi penjangka kerina dapat berada sesudah maupun sebelum FN pos-verbal yang merupakan satu-satunya argumen. Di mana pun posisi kerina, selalu menjelaskan/menunjukkan jumlah penjangka FN-nya. Jadi satu-satunya argumen FN pos- verbal dalam klausa intransitif BPD adalah subjek gramatikal.

Selanjutnya mari perhatikan posisi pengambangan penjangka pada contoh klausa transitif dengan verbal berafiks nasal BPD di bawah ini.

(11a)Me-maspas page kerina kalak perkuta

AKT-tumbuk padisemua orang kampung 'semua orang kampung menumbuk padi'

(11b)Me-maspas pagekalak perkuta kerina

AKT-tumbuk padi orang kampung semua 'semua orang kampung menumbuk padi'

(11c)Kerina me-maspas page kalak perkuta

semua AKT-tumbuk padi orang kampung 'semua orang kampung menumbuk padi'

(12a)Mang-alo inang-na kerina dukak-na

AKT-lawanibunya POS3TG semua anak-POS3TG

'semua anaknya melawan ibunya'

(12b)Ma-ngalo inang - na dukak-na kerina

AKT-lawan ibu -POS3TG anak - POS3TG semua 'semua anaknya melawan ibunya'

(12c)Kerina ma-ngalo inang - na dukak-na

semua AKT-lawan ibu- POS3TG anak-POS3TG

'semua anaknya melawan ibunya'

Dari contoh di atas FN 2 pos-verbal pada klausa $(11,12)$ adalahkalak perkuta (contoh 11,a,b,c) dan dukakna (contoh 12.a,b,c) yang merupakan argumen agen klausa tersebut Meskipun posisi penjangka kerina diubah-ubah, namun makna penunjuk jumlah tetap diberikan kepada agendukak na klausa yang bersangkutan. Hal ini berarti bahwa argumen agen (FN 2 pos-Verbal) klausa transitif berprefiks nasal adalah subjek gramatikal dalam BPD.

Pada klausa dengan verba transitif tanpa afiks dapat pula diamati posisi penjangka pada kalimat di bawah berikut:

(13a)mangan bubur kerina perempun i

makan bubur semua perempuan itu.

'semua perempuan itu makan bubur'

(13b)mangan bubur perempun i kerinana

Makan bubur perempuan itu semuanya 'perempuan itu semuanya makan bubur'

(13c) Kerinana mangan bubur perempun i

semuanya makan buburperempuan itu 'perempuan itu semuanya makan bubur'

(14a) men-tokor kereta kerina daholi i

Membeli motor semua laki-laki itu 'semua laki-laki itu membeli motor'

(14b)men-tokor kereta daholi i kerina na 
Membeli motor laki-laki itu semuanya

'semuanya membeli motor laki-laki itu semuanya'

(14c) Kerinana daholi i men-tokor kereta

semuanya laki-laki itu membeli motor

'semua laki-laki itu membeli motor'

Klausa transitif dengan verba tanpa afiks (verba dasar), penjangka kerinana menjelaskan jumlah FN 2 pos verbal. FN 2 pos-verbal tersebut adalah perempun i, daholi i merupakan agen dalam klausa tersebut; sedangkan FN 1 pos-verbal bubur, kereta merupakan pasien klausa tersebut. Jadi pada klausa transitif dengan verba tanpa afiks (verba zero) agen yang merupakan subjek gramatikal adal ah FN 2 pos- verbal, sedangkan pasien yang merupakan objek gramatikal adalah FN1pos-verbal.

\subsubsection{Uji subjek dengan perelatifan}

Keenan dan Comrie (1977) menyebutkan bahwa bahasa Inggris termasuk bahasa yang dapat merelatifkan semua relasi gramatikalnya, namun bahasa Bali termasuk bahasa yang hanya dapat merelatifkan subjek. Artawa (1998:15).

Untuk mengetahui strategi perelatifan sehubungan dengan kesubjekan dalam klausa transitif dengan verba zero BPD berikut. Klausa relatif dalam BPD dimarkahi (penanda relatif) oleh kata hubung si 'yang c

(15a) menum kopi bapak i

minumkopi Bapak itu

'Bapak itu minum kopi'

(15b) bapa [si mengenum kopi] i kalak perkutaku

Bapak [REL minum kopi] itu orang kampungku 'bapak yang minum kopi itu orang kampungku'

(15c) Kopi [ si menum bapak i] nggara

Kopi [REL bapak itu minum] panas 'kopi yang bapak itu minum] panas'

Dari contoh (15 a,b,c) kalimat di atas, BPD dapat merelatifkan kedua FN pos-Verbal, yaitu FN 2 pos- verbal kalak i yang berfungsi subjek dan FN 1 pos-verbal kopi yang berfungsi objek gramatikal. Jadi klausa transitif dengan verba zero dapat merelatifkan kedua FN pos-verbalnya yang masing-masing merupakan subjek dan objek gramatikal. Untuk mengetahui bagaimana keberterimaan klausa transitif (verba berafiks nasal) BPD, mari diamati contoh berikut.

(16a)kalak kota i me-nokor mobil

mem-beli mobil orang kota itu 'orang kota itu membeli mobil'

(16b)Kalak kota [si me-nokor mobil ] iturangku

orang kota [REL AKT beli mobil] itu abangku 'orang kota yang membeli mobil itu abangku'

(16c) *mobil [si me-nokor kalak kota i] naharga

mobil [REL AKT beli orang kota itu] mahal 'mobil yang membeli orang kota itu mahal'

(17a)Meng-endat pentu kalaki

AKT-tarik pintu orang itu 'orang itu menarik pintu'

(17b)Kalak [si meng- endat pentu]i belgah

orang [REL AKT tarik rotan] itu besar 'orang yang menarik pintu itu besar'

(17c)*Pentu [si meng- endat kalak]i nteger

pentu [REL AKT tarik orang] itu lurus 'rotan yang menarik orang itu lurus"' 
Dari contoh $(16,17 \mathrm{a}, \mathrm{b}, \mathrm{c})$ di atas memperlihatkan bahwa klausa transitif BPD dengan verba berafiks nasal hanya dapat merelatifkan FN 2 pos-verbal yang merupakan subjek gramatikal (yaitu kalak perkuta pada klausa 16 b dan kalak i pada klausa 17b). Apabila prefiks nasal pada verba dipertahankan, BPD tidak dapat merelatifkan FN 1 posverbal yang merupakan objek gramatikal (yaitu mobil pada klausa 16c dan pentu pada klausa 17c).

Pada klausa intransitif strategi perelatifan dapat diamati pada contoh berikut ini.

(18a)kundul puhun i

Duduk paman itu 'paman itu duduk'

(18b) puhun [si kundul] i bagak

paman [REL duduk]itu tampan sekali

'paman yang duduk itu tampan'

(19a)tertaba omakku

TertawaIbuku 'ibuku tertawa'

(19b) omakku [si tertaba]i ideng gajian

Ibuku [REL AKT tertawa] baru gajian 'ibuku yang tertawa itu baru gajian'

Ternyata dari contoh (18b) dan (19b) menunjukkan bahwa FN pos-Verbalpanguda i, omakku yang merupakan subjek gramatikal dan argumen satu-satunya (berperan sebagai agen) klausa tersebut dapat direlatifkan

Jadi perelatifanBPD memperlihatkan bahwa subjek (agen) dan objek gramatikal (pasien) klausa transitif dengan verba zero (tanpa afiks) dapat direlatifkan. Tetapi pada klausa transitif dengan verba berafiks nasal hanya agen yang dapat direlatifkan, Perelatifan pasien dengan tetap mempertahankan prefiks-nasal verbanya menyebabkan kalimat itu tidak berterima secara gramatikal. Sementara itu subjek gramatikal yang merupakan argumen agen satu-satunya pada klausa intransitif dapat direlatifkan. Konstruksi ini terbukti mirip dengan konstruksi yang ada dalam bahasa Inggris (bahasa akusatif). Pada konstruksi klausa transitif BPD dengan verba zero, agen mempunyai ciri sebagai subjek gramatikal (lihat 15a,b,c). Hal yang sama juga terjadi pada kalimat intransitif, agen merupakan subjek gramatikal (18a,b dan 19a,b). Kenyataan ini menyimpulkan bahwa agen merupakan subjek gramatikal dalam BPD. Dapat dikatakan bahwa uji perelatifan menunjukkan bahwa kesubjekan BPD dikondisikan secara morfologis dan sintaksis dengan isyarat gramatikal bahwa subjek dalam bahasa ini adalah agen secara semantis

\section{Kesimpulan}

Dengan seperangkat pengujian secara gramatikal terhadap relasi-relasi gramatikal BPD dapat diterangkan bahwa:

- Pada BPD, Relasi S pada klausa dasar selalu berperan sebagai A.

- Relasi S pada klausa BPD berprefiks nasal berada pada posisi FN2 pos-Verbal yang merupakan argumen A; Relasi O berada pada posisi FN1pos Verba yang merupakan argumen P.

- Pada BPD, relasi S dan O pada klausa verba zero dapat direlatifkan; sementara itu klausa verba berafiks nasal hanya relasi $S$ yang dapat direlatifkan.

- Pada BPD, relasi O diposisi langsung mengikuti verba; karena itu di antara V dan O tak dapat disisipi oleh adverbia apapun.

\section{References}

[1] Alsina, A. 1996. The Role of Argument Structure in Grammar: Evidence from Romance. Stanford, California: CSLI Publishers.

[2] Artawa, I Kt. 2000. -Alternasi Diatesis pada Beberapa Bahasa Nusantarall dalam Kajian Serba Linguistik untuk Anton Moeliono Pereksa Bahasa (editor: Purwo, B. K.). Jakarta: Universitas Katolik Indonesia Atma Jaya dan PT. BPK Gunung Mulia.

[3] Comrie, B. 1998. -Linguistic Typologyll dalam Newmeyer, F. J. (Editor). Linguistics: The Cambridge Survey. Vol. I. Hal.: $447-467$. Cambridge: Cambridge University Press.

[4] Dixon, R. W. M. 1998. -Subject and Object in Universal Grammar\| dalam Arnold, D., Atkinson, M., Durand, J., Groover, C., Sadler, L. (editor). Essay on Gramatical Theory and Universal Grammar. Hal.: 91-118). Oxford: Claredon Prebridgess.

[5] Gunarwan, Asim.2002. -Beberapa Kasus Pergeseran dan Pemertahanan Bahasa: Implikasinya pada Pembinaan Bahasa Lampungll. Makalah disampaikan pada Seminar Nasional Pembinaan Bahasa, Sastra, dan Budaya Daerah, Bandar Lampung,29-30 Oktober. 
[6] Grimes, Barbara F.2002. Kecenderungan Bahasa untuk Hidup atau Mati secara Global (Global Language Viability): Sebab,Gejala, dan Pemulihan untuk Bahasa-Bahasa yang Terancam Punahll. Dalam Bambang Kaswanti Purwo (Penyunting) PELBA 15. Jakarta:Lembaga Bahasa Atma Jaya

[7] Jufrizal.2007. -Tipologi Gramatikal Bahasa Minangkabaull(disertasi ). Denpasar : Program Doktor (S3).Linguistik Universitas Udayana.

[8] Lyons, J. 1988. Introduction to Theoritical Linguistics. Cambridge: Cambridge University Press. Palmer, F.R. 1994. Grammatical Roles and Relation. Cambridge : Cambridge University Press.

[9] Shibatani, M. dan TheodoraBynon (editor). 1999. Approaches to Language Typology. Oxford: Oxford University Press.

[10] Solin, Matsyuhito.1998. Dalam Tradisi dan Perubahan : Konteks Masyara 